\title{
Sistem Penyalaan Lampu Sein Otomatis Sepeda Motor Menggunakan Sensor Kecepatan Dan Keseimbangan
}

\author{
Ahson Rezza Subekti, Dian Efytra Yuliana \\ Program Studi Teknik Elektro Fakultas Teknik Universitas Islam Kadiri \\ Jl. Sersan Suharmadji No. 38 Kota Kediri \\ E-mail: ahsonrezza@gmail.com,dianefytra@uniska-kediri.ac.id
}

\begin{abstract}
Abstrak - Pada kendaraan sepeda motor kita di haruskan untuk mematikan lampu sein secara manual dan kebanyakan seseorang bahkan lupa mematikan lampu sein setelah menyalakannya pada saat setelah berbelok, pada permasalahan yang ada disini dapat di simpulkan bahwa di perlukannya suatu alat yang dapat mematikan lampu sein secara otomatis bahkan menyalakannya secara otomatis untuk mengurangi kesalahan komunikasi antar pengguna jalan yang diakibatkan oleh kelalaian seseorang mematikan lampu sein. Pada penelitian ini telah dilakukan pemanfaatan beberapa sensor yang bertujuan untuk menyalakan dan mematikan lampu sein secara otomatis pada sepeda motor.
\end{abstract}

Penelitian ini menganalisa penyalaan lampu sein otomatis sepeda motor dan diperoleh sensor kecepatan yang digunakan untuk membaca putaran roda dan mengaktifkan sensor keseimbangan stir kemudi sepeda motor, Sensor stir kemudi sepeda motor (rotary encoder) yang berguna memberi inputan untuk menyalakan lampu sein otomatis dengan nilai $<0$ maka lampu sein akan menyala kiri dan sebaliknya jika $>0$ maka lampu sein akan nyala kanan. Apabila sensor kecepatan (LM393) memiliki nilai berapapun >0rps dan sensor keseimbangan (MPU 6050) pada sudut $>80^{\circ}$ maka sein tidak akan menyala/mati. ketika sudut keseimbangan mendeteksi kemiringan sepeda motor dengan nilai $<\mathbf{8 0}^{\circ}$ ke kanan maka sein kanan akan menyala, apabila sudut keseimbangan mendeteksi kemiringan sepeda motor dengan nilai $<\mathbf{8 0}^{\circ}$ ke kiri maka sein kiri akan menyala.

\section{Kata Kunci-Arduino, Lampu Sein, LM393, MPU 6050}

\section{Pendahuluan}

Lampu sein adalah merupakan suatu alat yang sangat penting pada kendaraan, lampu sein merupakan salah satu alat komunikasi kendaraan selain suara klakson [1]. Lampu sein yang dipasang pada kendaraan roda empat jauh lebih pesat perkembanganya dari pada yang dipasang pada sepeda motor. Sebagai contoh, lampu sein mobil memiliki sebuah mekanisme yang dapat mati dengan sendirinya setelah mobil berbelok. Akan tetapi lampu sein pada sepeda motor, akan tetap menyala apabila saklar tidak dikembalikan pada posisi semula. Jika pengemudi lalai tidak mematikan lampu sein dalam waktu yang lama dapat mengakibatkan kecelakaan karena komunikasi pengendara dengan pengguna jalan yang lain terganggu [2]. Kesalahan dalam mengoperasikan lampu sein akan mempunyai dampak yang fatal bagi pengendaranya dan juga pengendara lain, karena kelalaian ini bisa menyebabkan kesalahan komunikasi antara pengendara lain disekitar. Kesalahan yang biasanya terjadi dalam pengoperasian lampu sein sepeda motor antara lain yaitu tidak menyalakan lampu sein ketika akan belok dan tidak mematikan lampu sein kembali ketika kendaraan sudah belok, serta tidak menyalakan lampu sein sesuai arah belokan kendaraan.

Dengan berkembangnya teknologi saat ini yang semakin canggih, sejalan dengan kemajuan zaman maka penggunaan teknologi semakin meningkat. Pengembangan prototipe lampu sein secara otomatis telah dilakukan [3][4][5]. Dalam sebuah alat, sensor merupakan salah satu bagian penting dalam mengembangkan sistem berbasis otomatisasi. Oleh karena itu peneliti ingin membuat penelitian dengan mengembangkan lampu sein sepeda motor yang sudah ada. Salah satunya yaitu mengembangkan sistem lampu sein sepeda motor menggunakan sensor kecepatan LM393, Sensor keseimbangan (MPU6050) dan juga Arduino Uno sebagai unit pemroses dari output sensor tersebut [6]. Dari pengembangan lampu sein sepeda motor ini diharapkan dapat mengurangi angka kecelakaan akibat kelalaian dari pengemudi dalam menyalakan dan mematikan lampu sein sepeda motor.

\section{BAHAN DAN METODE}

\section{A. Prosedur Penelitian}

Berdasarkan penelitian yang telah dilakukan dan studi pustaka sebelumnya, kerangka konseptual penelitian yang mendasari penelitian ini antara lain meliputi desain, metode, atau pendekatan yang digunakan dalam menjawab permasalahan penelitian atau studi untuk mencapai tujuan penelitian, serta tahapan penelitian secara rinci, singkat, dan jelas, dapat di lihat pada gambar diagram berikut:

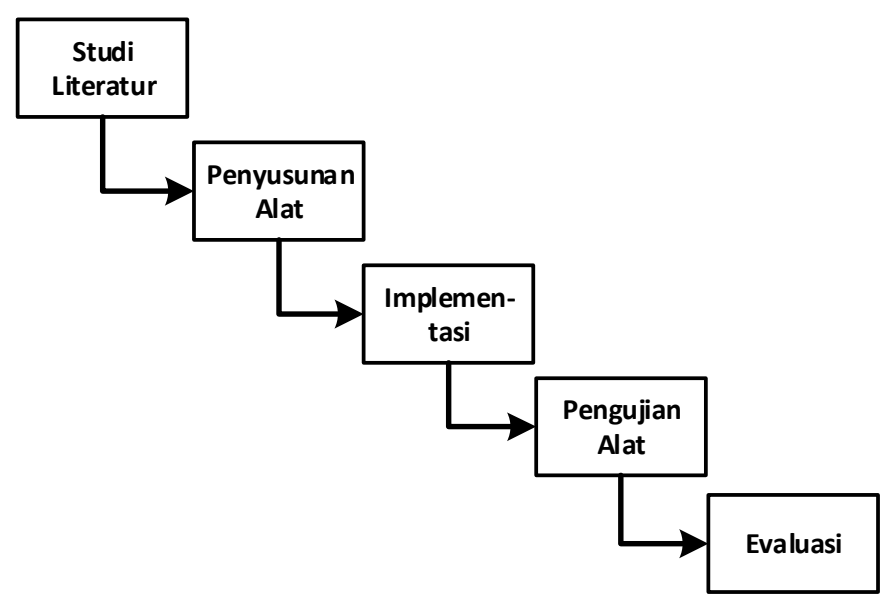

Gambar 1. Bagan Prosedur

Studi literatur dalam penelitian ini dilakukan untuk mengetahui dan mempelajari sumber referensi atau dasar teori yang berkaitan dengan penelitian yang sedang 
dikerjakan, baik berupa buku, jurnal, web maupun komunitas grup facebook maupun telegram, sehingga dapat menambah wawasan sebelum melaksanakan penelitian.

\section{B. Penyusunan Alat}

Perancangan alat ini dimaksudkan agar dalam penyusunan sistem maupun program ini dapat berjalan sesuai dengan rencana sehingga mampu mengurangi kesalahan dalam pembuatan perangkat keras maupun program yang sedang dikerjakan.

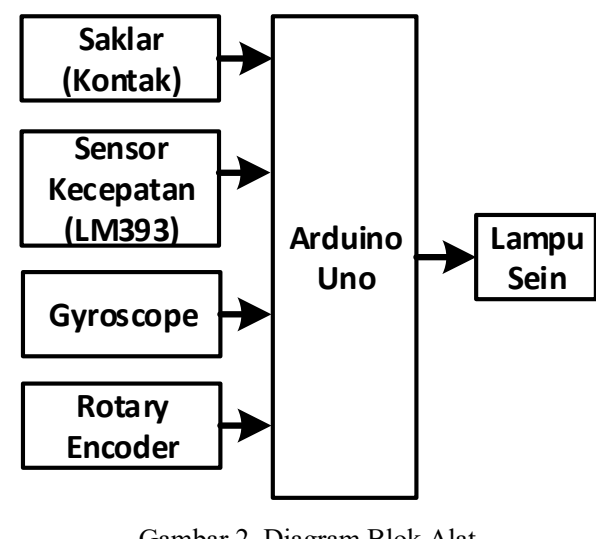

Dalam perancangan alat, ada beberapa sensor yang digunakan yaitu Sensor Kecepatan sebagai input pembacaan berupa kecepatan angular menggunakan modul LM393 [6]. Modul LM393 merupakan modul sensor optocoupler yang menggunakan IC LM393 yang merupakan IC OPAMP sebagai pembanding. Input dari IC LM393 yang digunakan dalam penelitian ini adalah sensor inframerah dengan jarak pemancar dan penerima adalah $1 \mathrm{~cm}$, dimana Sensor infra merah baik digunakan pada jarak kurang dari $12 \mathrm{~cm}$ [7]. Rotary Encoder dalam penelitian ini digunakan untuk mendeteksi sudut putar stir kemudi sepeda motor yang juga berguna untuk input penyalaan lampu sein secara otomatis dengan membaca putaran rotary encoder, jika putaran rotary encoder memiliki nilai 1 (ke kanan) maka sein kanan yang akan menyala, sebaliknya apabila rotary memiiliki nilai -1 (ke kiri) maka sein kiri akan menyala. Sensor Gyroscope (MPU 6050) dalam penelitian ini digunakan sebagai sensor pembaca kemiringan sepeda motor yang akan digunakan sebagai input Arduino Uno untuk menyalakan sein secara otomatis dengan kemiringan kanan atau kiri yang telah ditentukan. MPU 6050 sendiri sudah memiliki Digital Motion Processors (DMP) yang akan mengolah data mentah dari masing-masing sensor [8]. Unit kendali yang digunakan dalam penelitian ini yaitu Arduino Uno. Dimana Arduino Uno merupakan papan pengembangan (development board) rangkaian elektronik berbasis mikrokontroller ATmega328 [9]. Output dari rangkaian ini berupa flash lampu sein. Prototipe sistem penyalaan lampu sein otomatis pada sepeda motor menggunakan sensor kecepatan dan keseimbangan dalam penelitian ini disajikan oleh Gambar 3 sebagai berikut:

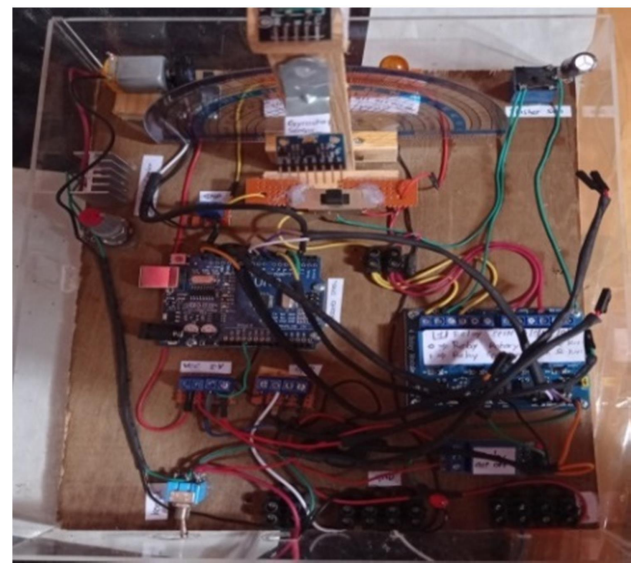

Gambar 3. Prototipe Alat

\section{Perancangan Software}

Pada perancangan software atau perangkat lunak yang digunakan dalam penelitian ini tentunya tidak lepas dari software Arduino IDE sebagai bahasa pemrograman untuk Arduino Uno yang bersifat open source [10][11]. Berikut ini adalah flowchart yang digunakan dalam mendesai program menggunakan Arduino IDE yang disajikan oleh Gambar 4.

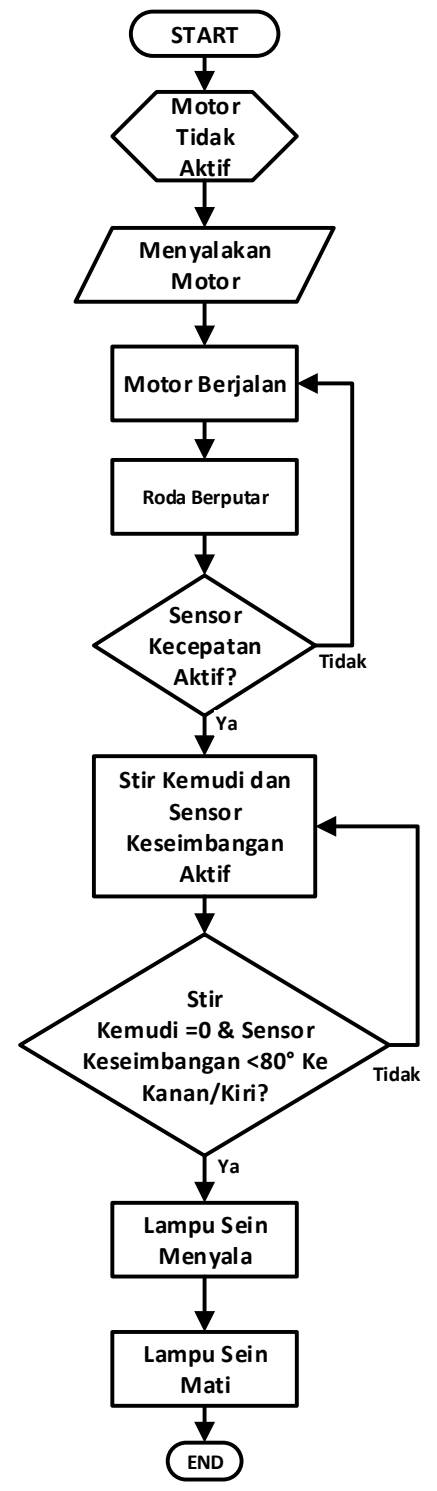

Vol 8 No.2@ 2021 Ahson Rezza Subekti \& Dian Efytra Yuliana 2021
ISSN 2615-5788 Print (2615-7764)

JURNAL TEKNIK ELEKTRO DAN KOMPUTER TRIAC 
Gambar 3. Flowchart Sistem

Berdasarkan diagaram flowchart pada gambar 4, proses kerja alat penyalaan lampu sein dengan memanfaatkan sensor kecepatan pada tahap pertama yaitu menyalakan motor. Ketika motor sudah menyala maka tahap selanjutnya yaitu menjalankan motor, ketika motor sudah berjalan disinilah sensor kecepatan membaca putaran roda yang mengirimkan data ke Arduino Uno dan akan terhubung ke stir kemudi dan juga sensor keseimbangan. Stir kemudi telah di tentukan apabila mendapatkan nilai 1 maka sein kanan akan menyala, dan sebaliknya apabila nilai stir kemudi -1 maka sein kiri yang akan menyala dengan alur sebagai berikut. Output dari stir kemudi (rotary encoder) akan terhubung ke dalam Arduino Uno yang akan memproses data tersebut dan akan memberi input-an ke dalam relay module dan berguna untuk menyalakan lampu sein mana yang harus menyala dalam kondisi ini.

Selain stir kemudi sepeda motor untuk input penyalaan lampu sein juga menggunakan sensor keseimbangan yaitu (MPU 6050), ketika sensor keseimbangan mempuyai nilai kemiringan ke kanan atau ke kiri kurang dari $80^{\circ}$ maka lampu sein akan menyala, yaitu dengan alur yang sama dengan stir kemudi. Output dari sensor keseimbangan akan terhubung dengan Arduino Uno yang akan memproses data tersebut dan akan memberikan inputan kepada relay module yang digunakan sebagai saklar penyalaan lampu sein secara otomatis tergantung input dari arduino dengan data yang diperoleh dari sensor-sensor yang ada.

\section{HASIL DAN PEMBAHASAN}

\section{A. Pengujian Gyroscope}

Pengujian gyroscope ini ditujukan untuk mengetahui apakah gyroscope (MPU6050) mampu mendeteksi kemiringan sepeda motor. Dalam penelitian ini, hasil pengujian gyroscope untuk mendeteksi kemiringan sepeda motor ditunjukkan oleh Gambar 4 sebagai berikut.

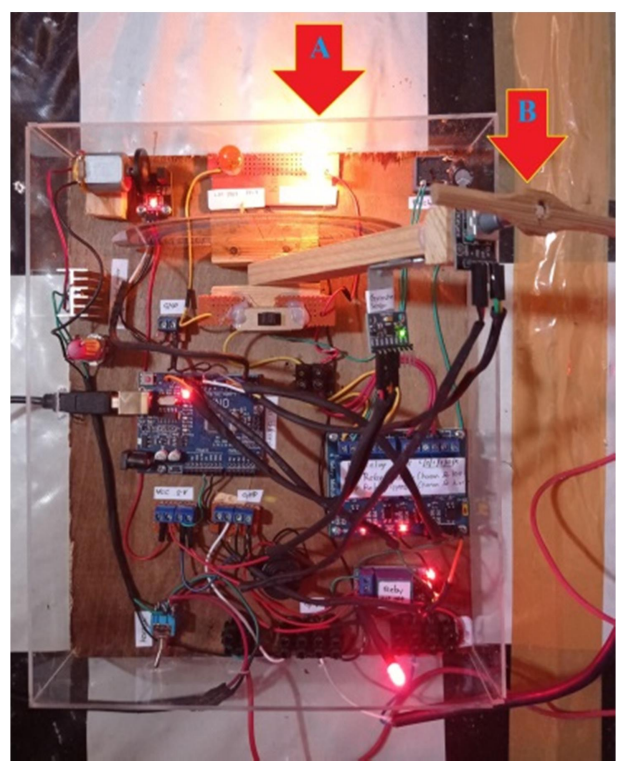

Gambar 4. Uji Coba Gyroscope (MPU6050)

Gambar 4 di atas menujukkan bahwa sensor keseimbangan (MPU 6050) dapat mendeteksi kemiringan ISSN 2615-5788 Print (2615-7764) JURNAL TEKNIK ELEKTRO DAN KOMPUTER TRIAC

Vol 8 No.2@ 2021 Ahson Rezza Subekti \& Dian Efytra Yuliana 2021 dengan sudut kemiringan ke kanan kurang dari $80^{\circ}$ dan sistem dapat menyalakan lampu sein kanan secara otomatis Ketika kemiringan sensor keseimbangan ditunjukkan pada gambar dengan ditandai arah panah dengan huruf "B", dan sebaliknya jika kondisi gyroscope mendeteksi kemiringan sepeda motor ke kiri kurang dari $80^{\circ}$ maka sein kiri akan menyala secara otomatis.

Perhitungan sudut kemiringan sepeda motor yang digunakan dalam sistem penyalaan lampu sein otomatis ini dilakukan dengan cara manual yaitu dengan menggunakan busur derajat yang ditempel pada alat, perhitungan sudut dari setiap kemiringan dinilai dari $0^{\circ}$ pada sudut dari kiri dan $0^{\circ}$ pada sudut dari kanan. Pada kondisi kendaraan sepeda motor tegak lurus maka sudut kemiringan sepeda motor ditentukan dengan nilai sudut $90^{\circ}$.

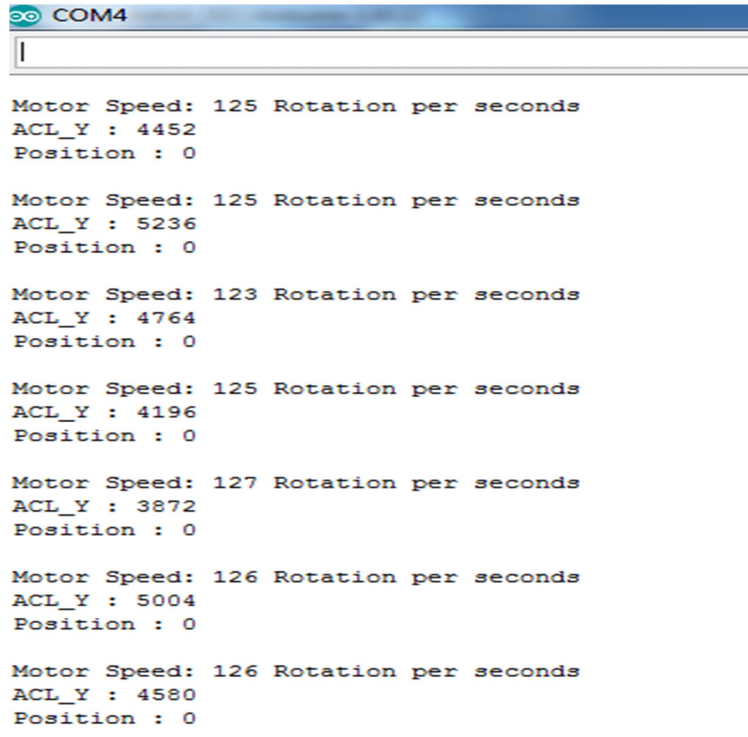

Gambar 5. Pengambilan Data Gyroscope dari Serial Monitor

Dari tampilan serial monitor yang ditunjukkan oleh gambar 5, output sensor yaitu "motor speed" sebagai output nilai dari sensor kecepatan jika nilai kecepatan $>0$ maka sensor membaca putaran roda, "ACL_Y" adalah nilai output dari sensor keseimbangan (MPU 6050) jika nilai kemiringan sepeda motor $<1800$ maka sein kiri akan menyala secara otomatis dan sebaliknya jika kemiringan sepeda motor $>1800$ maka sein kanan akan menyala secara otomatis. Pada tampilan serial monitor yang ditunjukkan oleh gambar 5 menunjukkan bahwa nilai "ACL_Y" lebih dari 1800 maka dalam kondisi ini dapat ditentukan bahwa lampu sein sepeda motor dapat menyala kanan secara otomatis. "Position" adalah nilai output dari stir kemudi jika nilai stir kemudi $<0>$ maka lampu sein akan menyala kanan atau kiri.

\section{B. Pengujian Putaran Stir Kemudi}

Pengujian putaran stir kemudi pada sepeda motor ini digunakan untuk mengetahui apakah sensor rotary encoder yang dipasang pada stir kemudi sepeda motor dapat digunakan untuk mendeteksi putaran stir kemudi sepeda motor. Hasil dari pengujian putaran stir kemudi sepeda motor ditunjukkan oleh Gambar 6 sebagai berikut. 


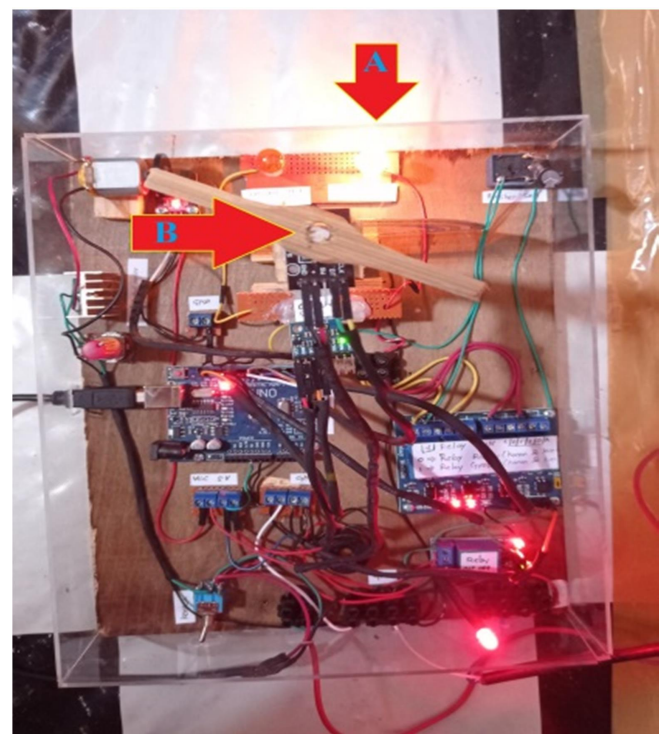

Gambar 6. Uji Coba putaran stir kemudi (rotary encoder)

Dari gambar 6 menunjukkan apabila stir kemudi sepeda motor (rotary encoder) yaitu pada gambar 6 ditandai dengan huruf "B" dalam kondisi dibelokkan ke kanan maka akan menyalakan lampu sein kanan yang pada gambar 6 ditandai dengan anak panah huruf "A". Saat menyalakan lampu sein menggunakan putaran stir kemudi sepeda motor ini terjadi karena output dari stir kemudi sepeda motor dengan nilai $>0$ untuk menyalakan lampu sein kanan, atau sebaliknya apabila stir kemudi sepeda motor dibelokkan ke kiri maka akan menyalakan lampu sein kiri dengan nilai output putaran $<0$. Dalam kondisi ini nilai putaran stir kemudi sepeda motor dibatasi dengan nilai putaran maksimal sebesar $90^{\circ}$ ke kanan dan nilai putaran maksimal $90^{\circ}$ ke kiri. Hal ini dilakukan dengan pembatasan dikarenakan pada rotary encoder dapat diputar hingga putaran $360^{\circ}$ yang bisa membuat kerusakan pada program yang sudah dibuat.

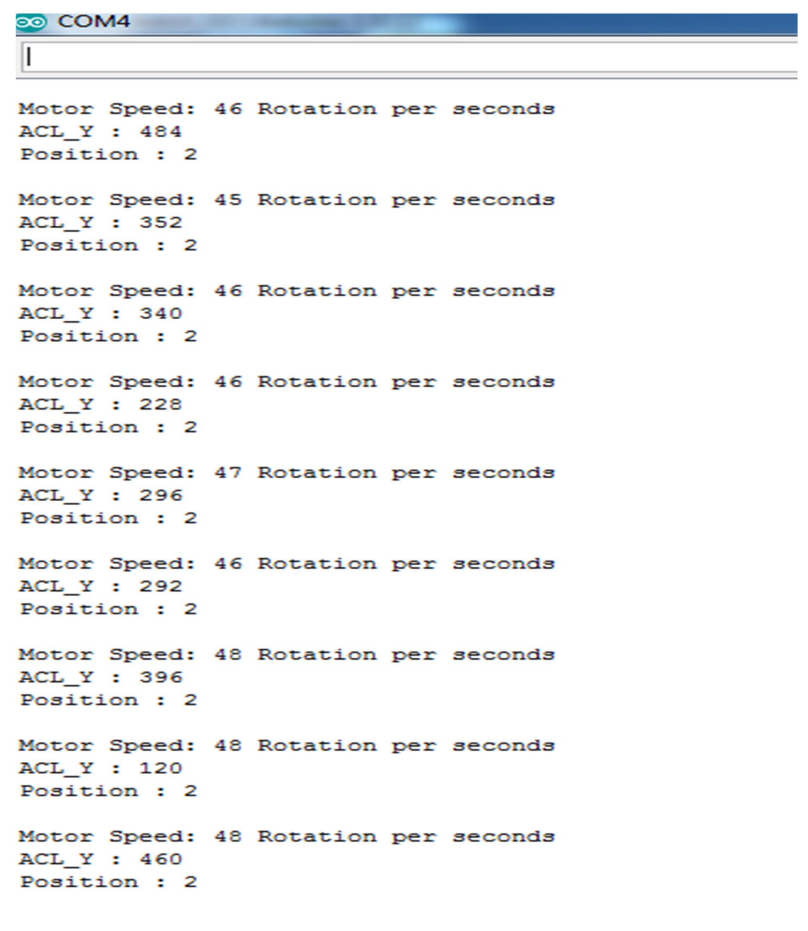

Gambar 7. Pengambilan Data Rotary Encoder dari Serial Monitor ISSN 2615-5788 Print (2615-7764) JURNAL TEKNIK ELEKTRO DAN KOMPUTER TRIAC
Gambar 7 menunjukkan bahwa stir kemudi sepeda motor mempunyai nilai putaran lebih dari 0 yaitu pada gambar di atas ditandai dengan nama "position" jadi pada kondisi ini dapat ditentukan bahwa lampu sein kanan menyala dengan otomatis. Dan apabila nilai putaran stir kemudi sepeda motor kembali 0 maka lampu sein akan mati.

\section{Percobaan kondisi kendaraan terjatuh}

Percobaan kondisi kendaraan terjatuh ini digunakan untuk mengetahui apakah alat yang dibuat dalam penelitian ini dapat memutus arus kontak kendaraan bermotor ketika diberikan kemiringan diatas $20^{\circ}$ sehingga sepeda motor dapat mati dengan sendirinya jika terjatuh. Hasil percobaan dari kondisi sepeda motor terjatuh ditunjukkan oleh Gambar 8 sebagai berikut.

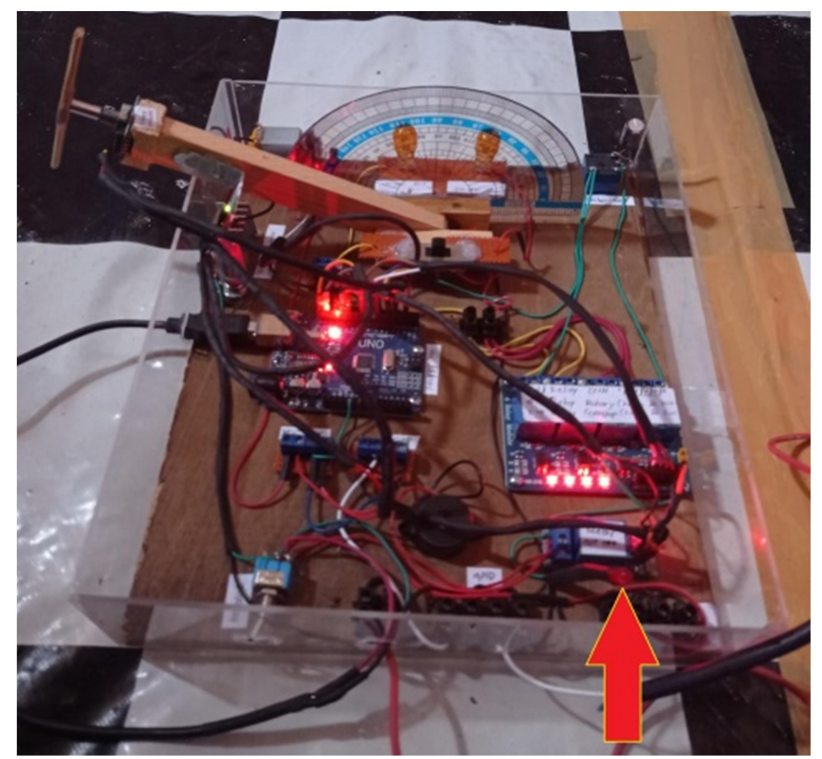

Gambar 8. Uji Coba kemiringan kendaraan kondisi terjatuh

Tanda panah yang ditunjukkan pada Gambar 8 menujukkan bahwa LED mati yang digunakan sebagai tanda bahwa mesin dalam kondisi mati, jadi pada saat sensor gyroscope mencapai nilai kemiringan kurang dari $20^{\circ}$ maka akan memutus arus kontak kendaraan yang membuat sepeda motor mati. Nilai kemiringan ini berlaku untuk kemiringan kendaraan ke kanan atau ke kiri. Hal ini dilakukan hanya sebagai tambahan pemanfaatan alat karena pada suatu kendaraan harus dilengkapi dengan sistem keamanan. Pada dasarnya sistem keamanan ini berguna sebagai keamanan ketika pengendara terjatuh, saat posisi kendaraan terjatuh maka otomatis mesin kendaraan akan mati sehingga mengurangi tingkat cidera pengendara yang diakibatkan tuas gas bisa tertarik secara spontan pada saat kecelakaan sehingga membuat pengendara bisa mengalami cidera yang serius akibat dari kecelakaan.

\section{Pengujian alat secara keseluruhan}

Pengujian sistem penyalaan lampu sein otomatis sepeda motor menggunakan sensor kecepatan dan keseimbangan pada penelitian ini dilakukan secara bersamaan pada tanggal 15 oktober 2020, pada hari kamis dan di lakukan pada siang hari 09:00 Pada pengujian alat ini nilai range kecepatan putaran roda disajikan oleh Tabel I.

Vol 8 No.2 @ 2021 Ahson Rezza Subekti \& Dian Efytra Yuliana 2021 
TABLE I NILAI RANGE KECEPATAN

\begin{tabular}{|c|c|c|}
\hline No & $\begin{array}{c}\text { Nilai Range } \\
\text { Kecepatan (rps) }\end{array}$ & Keterangan \\
\hline 1 & $30-50$ & Lambat \\
\hline 2 & $50-70$ & Sedang \\
\hline 3 & $>70$ & Cepat \\
\hline
\end{tabular}

Dari nilai range kecepatan putaran roda sepeda motor yang ditetapkan oleh Tabel I dapat diperoleh hasil pengujian sistem penyalaan lampu sein otomatis sepeda motor menggunakan sensor kecepatan dan keseimbangan secara keseluruhan sebagaimana disajikan oleh Tabel II sebagai berikut.

TABLE II. HASIL KESELURUHAN PERCOBAAN ALAT

\begin{tabular}{|c|c|c|c|c|c|c|c|}
\hline \multirow{2}{*}{ No } & \multirow{2}{*}{ LM393 } & \multicolumn{2}{|c|}{ MPU6050 } & \multicolumn{2}{c|}{ Stir Kemudi } & \multicolumn{2}{c|}{ Lampu Sein } \\
\cline { 2 - 7 } & \multirow{2}{*}{ Speed } & \multicolumn{2}{|c|}{ Sudut } & \multicolumn{2}{|c|}{ Belok } & \multicolumn{2}{c|}{} \\
\cline { 2 - 7 } & Kanan & Kiri & Kanan & Kiri & Kanan & Kiri \\
\hline 1 & $30 \mathrm{rps}$ & $100^{\circ}$ & - & 1 & 0 & ON & OFF \\
\hline 2 & $50 \mathrm{rps}$ & $130^{\circ}$ & - & 0 & 0 & ON & OFF \\
\hline 3 & $30 \mathrm{rps}$ & - & $80^{0}$ & 0 & 1 & OFF & ON \\
\hline 4 & $50 \mathrm{rps}$ & - & $60^{0}$ & 0 & 0 & OFF & ON \\
\hline 5 & $70 \mathrm{rps}$ & $140^{\circ}$ & - & 1 & 0 & ON & OFF \\
\hline 6 & $70 \mathrm{rps}$ & - & $50^{0}$ & 0 & 1 & OFF & ON \\
\hline 7 & $100 \mathrm{rps}$ & $160^{\circ}$ & - & 1 & 0 & OFF & OFF \\
\hline
\end{tabular}

Pada hasil pengujian sistem secara keseluruhan yang disajikan oleh Tabel II diperoleh hasil bahwa ketika sensor kecepatan (LM393) memiliki nilai berapapun (>0 rps) dan sensor keseimbangan sepeda motor (gyroscope) memiliki sudut kemiringan lebih dari $80^{\circ}$ maka sein tidak akan menyala/mati karena tidak aktif, dalam kondisi ini sudah ditentukan bahwa sein akan menyala ke kanan secara otomatis apabila mempunyai kemiringan kurang dari $80^{\circ} \mathrm{ke}$ kanan dan dalam kondisi kemiringan kurang dari $80^{\circ}$ ke kiri maka lampu sein kiri akan menyala secara otomatis. Berbeda dengan stir kemudi sepeda motor karena stir kemudi sepeda motor hanya membutuhkan input belokan dengan nilai 1 sampai 4 untuk menyalakan lampu sein kanan dan -1 sampai -4 untuk menyalakan lampu sein kiri serta dalam kondisi tanpa input-an atau 0 maka lampu sein tidak akan menyala. ketika sudut keseimbangan miring ke kanan dengan nilai kurang dari $20^{\circ}$ maka mesin sepeda motor akan mati (engine stop). Kondisi ini juga berlaku pada sudut kemiringan kurang dari $20^{\circ}$ ke kiri yang akan membuat mesin sepeda motor mati secara otomatis (engine stop).

\section{KESIMPULAN}

Kesimpulan yang dapat diambil berdasarkan hasil pengujian dari "sistem penyalaan lampu sein otomatis sepeda motor menggunakan sensor kecepatan dan keseimbangan" adalah sebagai berikut:

1. Dalam pengujian ini rancangan yang digunakan dengan bantuan Arduino Uno sebagai microcontroller, sensor

[9] D. Erwanto,
No.2 @ 2021 Ahson Rezza Subekti \& Dian Efytra Yuliana 2021

dapat menjalankan program yang diinginkan yaitu menyalakan lampu sein secara otomatis.

2. Dalam pengujian ini rancangan yang digunakan berupa sensor kecepatan menggunakan modul LM393 dan kesimbangan stir kemudi sepeda motor berupa modul MPU 6050 sebagai input-an Arduino Uno dapat menyalakan dan mematikan lampu sein sepeda motor secara otomatis.

3. Berdasarkan analisis yang telah dilakukan diperoleh kesimpulan bahwa sensor kecepatan dapat berjalan dengan semestinya sehingga dapat berguna untuk mendeteksi putaran roda sepeda motor dan mengaktifkan sensor keseimbangan stir kemudi sepeda motor.

4. Disamping itu sensor keseimbangan stir kemudi sepeda motor (MPU 6050) dapat berjalan dengan semestinya sehingga dapat memberi input-an untuk menyalakan lampu sein sepeda motor secara otomatis.

5. Apabila sensor kecepatan (LM393) memiliki nilai berapapun $>0$ rps dan sensor keseimbangan (gyroscope) pada sudut $>80^{\circ}$ maka sein sepeda motor tidak akan menyala/mati. ketika sudut keseimbangan miring dengan nilai $<80^{\circ}$ maka sein tersebut akan menyala, apabila kurang dari $20^{\circ}$ maka mesin sepeda motor akan mati (engine stop).

\section{DAFTAR PUSTAKA}

[1] Y. V. Via, B. Rahmat, R. G. Saputra, dan others, "IMPLEMENTASI BERBASIS ARDUINO UNO R3 UNTUK PROTOTIPE LAMPU SEIN OTOMATIS PADA KENDARAAN," in Prosiding Seminar Nasional SANTIKA Ke-1 2019, 2019, hal. 233-237.

[2] F. R. Adha, M. Yusro, dan P. Yuliatmojo, "SISTEM LAMPU SEIN MATI OTOMATIS, DETEKSI TITIK BUTA PENGENDARA, DAN ENGINE STOP BERBASIS ARDUINO PADA SEPEDA MOTOR," J. Pendidik. VOKASIONAL Tek. Elektron., vol. 1, no. 1, hal. 18-21, 2018

[3] Y. B. Praharto, C. Wicaksana, dan others, "Perancangan Alat Penetral Lampu Sein Sepeda Motor Otomatis Berbasis ARDUINO R3," Iteks, vol. 8, no. 1, 2016.

[4] W. Warsono, "Rancang Bangun Sistem Kontrol Otomatis Lampu Sein dan Lampu Rem Sepeda Motor Berbasis Mikrokontroler Arduino," Universitas Negeri Padang, 2020

[5] I. Dwisaputra, P. Silalahi, B. Cahyawan, dan I. Akbar, "Lampu Sein Helm Sepeda Berbasis Voice Recognition," Manutech J. Teknol. Manufaktur, vol. 11, no. 01, hal. 20-25, 2019.

[6] R. A. Putra dan others, "Pemanfaatan LM393 IR Sensor Module Sebagai Pengukur Kecepatan Rotasi Berbasis Mikrokontroler," $J$. Hadron, vol. 1, no. 1, hal. 12-15, 2019.

[7] A. Nurmastika, D. Erwanto, A. D. Rosanti, dan F. A. Fiolana, "Rancang Bangun Alat Pengukur Kadar Asam Askorbat pada Buah dengan Metode Titrasi Iodimetri,” 2018.

[8] B. Firman, "Implementasi Sensor IMU MPU6050 Berbasis Serial I2C pada Self-Balancing Robot," J. Teknol. Technoscientia, hal. 1824, 2016.

https://journal.trunojoyo.ac.id/triac 
Tegangan Panel Surya Berbasis Internet of Things," MULTITEK Indones., vol. 14, no. 1, hal. 1-12, 2020.

[10] M. Fezari dan A. Al Dahoud, "Integrated Development Environment ‘IDE’ For Arduino,” WSN Appl., hal. 1-12, 2018.
[11] M. A. Fikri, D. Erwanto, dan D. E. Yuliana, "Rancang Bangun Alat Prediksi Kondisi Tubuh Ideal Menggunakan Metode Fuzzy Logic Sugeno," Setrum Sist. Kendali-Tenaga-Elektronika-TelekomunikasiKomputer, Jun 2018.
ISSN 2615-5788 Print (2615-7764)

JURNAL TEKNIK ELEKTRO DAN KOMPUTER TRIAC

https://journal.trunojoyo.ac.id/triac
Vol 8 No.2@ 2021 Ahson Rezza Subekti \& Dian Efytra Yuliana 2021 